\title{
3-D Airway Analysis Related to Facial Morphology
}

\author{
Análisis 3-D de la Vía Aerea Relacionado con la Morfología Facial
}

\author{
Victor Ravelo $^{1}$; Gabriela Olate ${ }^{1}$; Maria Paz Moya ${ }^{1,2}$; Leonardo Brito ${ }^{1,2}$; Ivonne Garay ${ }^{3}$ \& Sergio Olate ${ }^{3,4}$
}

RAVELO, V.; OLATE, G.; MOYA, M. P.; BRITO, L.; GARAY, I. \& OLATE, S. 3-D Airway analysis related to facial morphology. Int. J. Morphol., 38(2):423-426, 2020.

SUMMARY: The aim of this investigation was to define the volume and area of the airway in subjects with Class II and Class III skeletal deformity. A cross-sectional study was designed including subjects with facial deformity defined by Steiner's analysis in subjects with indication of orthognathic surgery who presented diagnosis by cone beam computerised tomography. We determined the measurements of maximum area, minimum area and volume of the airway. The data were compared using Spearman's test, with statistical significance defined as $p<0.05 .115$ subjects were included: $61.7 \%$ Class II and $38.3 \%$ Class III, mean age 27.8 years $( \pm 11.6)$. A significant difference was observed in the area and volume measurements in the groups studied, with significantly smaller measurements found in Class II ( $\mathrm{p}=0.034)$. The minimum area was $10.4 \mathrm{~mm} 2$ smaller in Class II patients than in Class III, while the general volume of the airway was $4.1 \mathrm{~mm} 3$ smaller in Class II than in Class III. We may conclude that Class II subjects present a smaller airway volume than Class III subjects.

KEY WORDS: Facial deformity; Airway; OSAHS; Orthognathic surgery.

\section{INTRODUCTION}

More attention has been paid to sleep pathology in recent years due to the high level of comorbidity and complexity of the disease. Obstructive sleep apnea-hypopnea syndrome (OSAHS) is a chronic disorder characterised by repetitive episodes of total or partial collapse of the upper airway during sleep, causing progressive asphyxia for more than 10 seconds (Spicuzza et al, 2015.).

Some risk factors have been described as possible triggers of OSAHS, such as age, male sex, obesity and craniofacial deformities; the latter two present a positive correlation in patients diagnosed with OSAHS (Neelapu et al., 2017; Albajalan et al.,2011).

Some investigations show a relation between airway size and morphological facial pattern; the position of the maxilla and the mandible in the anteroposterior direction influence this volume (Sprenger et al., 2017.) This anatomical variation may be further exposed where there is a vertical facial increment in conjunction with mandibular retraction, causing pharyngeal reduction of the airway and respiratory collapse (Neelapu et al., 2017).
Studies show that different morphological patterns are linked with an increase or diminution of the vertical facial position, and with sagittal alterations of the maxilla and mandible, generating alterations in the airway volume (Muto et al. 2008; Zheng et al. 2014). This morphology creates the conditions for alterations in the respiratory mechanism (Zheng et al. 2014) and increases the risk of associated pathologies (Gong et al. 2018). In this way, morphological craniomaxillofacial anomalies generate significant functional changes which involve oral dysfunction, labial incompetence, functional alterations and muscular imbalances (Sprenger et al. 2017).

In cases of diagnosis of severe respiratory alterations like OSAHS, different treatment modalities have been proposed like the continuous positive airway pressure (CPAP) mask. The main problem with these is the failure of patients to adhere to the treatment, since $17-54 \%$ of patients do not use the CPAP for a prolonged period. Surgical alternatives have also been proposed. One viable option is orthognathic surgery (Ferraz et al. 20016) since it allows an increase in the anteroposterior and lateral relations of the

\footnotetext{
${ }^{1}$ Facultad de Ciencias de la Salud, Universidad Autónoma de Chile, Temuco, Chile.

${ }^{2}$ Programa de Doctorado en Ciencias Morfológicas, Universidad de La Frontera, Temuco, Chile.

${ }^{3}$ Facultad de Odontología, Universidad de La Frontera, Temuco, Chile.

${ }^{4}$ Centro de Excelencia en Estudios Morfológicos y Quirúrgicos (CEMyQ), Temuco, Chile.
} 
maxilla, with consequent increase in airway volume (Veys et al., 2017; Zaoui et al., 2019).

The aim of this research was to analyse the airway volume in subjects with different skeletal conditions by $3 \mathrm{D}$ imaging.

\section{MATERIAL AND METHOD}

A cross-sectional study was carried out to identify the airway volume in adult subjects with different sagittal skeletal anomalies where orthognathic surgery is indicated; all the images obtained were used for pre-surgery facial diagnosis. The subjects enrolled in the study voluntarily, signing an informed consent document. The investigation safeguarded the integrity of the participants and complied with the Helsinki Declaration.

The subjects included were subjects of both sexes, aged over 18 years, who presented a Class II facial deformity (Steiner analysis with angle $>2^{\circ}$ ) or a Class III deformity (Steiner analysis with angle $<2^{\circ}$ ); subjects with previous facial surgery, background of facial trauma or conditions which signified alterations of the facial morphology were excluded.

Images were taken of all the subjects using the NewTom 3D Tomograph, Model VGi EVO (Verona, Italy), viewing field $24 \mathrm{x} 19 \mathrm{~cm}$. and exposure parameters $110 \mathrm{kV}, 8 \mathrm{~mA}, 15 \mathrm{sec}$. The image was obtained by a technician who specialises in this kind of imaging; the patient was positioned immobile in a vertical position while the image was taken, with lips in repose and without forcing any position of the body.

The image was analysed using the NNT New Tom software (Imola, Italy) by a specialist in Maxillofacial Radiology who delimited the pharyngeal space in a rectangular area; the reference points used were:

- Anterior position: posterior nasal spine in the sagittal plane and choanae in the axial plane.

- Posterior position: posterior wall of the pharynx.

- Upper position: highest point of the nasopharynx.

- Low position: low hyoid bone, at the inferior edge of the vertebral body of $\mathrm{C} 4$.
Based on these variables, a statistical analysis was carried out to determine the relation between them. Spearman's test was used, with threshold of statistical significance $\mathrm{p}<0.05$.

\section{RESULTS}

In this research, 115 subjects were included. According to Steiner's proposed definition, there were 71 skeletal Class II subjects $(61.7 \%)$ and 44 Class III subjects $(38.3 \%)$ (Figs. 1 and 2). The subjects included presented a mean age of $27.8 \pm 11.6$ years (range 18 to 63 years). 46 subjects $(40 \%)$ were male and $69(60 \%)$ were female. Table I identifies the airway volumes observed in the different measurement levels.

Using Spearman's test, the airway volume was significantly greater in Class III subjects ( $\mathrm{p}=0.034$ ). The subjects also presented significant differences by sex $(\mathrm{p}=0.0159)$, although this difference may be associated with the fact that the Class II group of subjects (smaller airway volume) contained almost twice as many female as male subjects.

When each measurement was examined independently, it was observed that at all levels the subjects with Class II characteristics presented smaller airway measurements than Class III subjects. In the minimum area reported in each class, Class III presented an area $10.4 \mathrm{~mm}^{2}$ larger than Class II; in the maximum area, Class III presented an area $46.6 \mathrm{~mm}^{2}$ larger than Class II; in the total volumetric measurement, Class III subjects presented a mean volume $4.1 \mathrm{~mm}^{3}$ larger than Class II subjects.

\section{DISCUSSION}

Facial morphology defines conditions of form and function which are essential for life and quality of life. In these analyses, 3D studies have evolved to explain morphology better and to define the best treatments.

Studies with 2D images have been used for many years and help to define certain standards (Olate et al, 2016);

Table I. Distribution of the 115 subjects included by type of facial deformity and airway volume.

\begin{tabular}{lcccccc}
\hline & Minimum area $\left(\mathrm{mm}^{2}\right)$ & \multicolumn{3}{c}{ Maximum area $\left(\mathrm{mm}^{2}\right)$} & \multicolumn{2}{c}{ Total volume $\left(\mathrm{mm}^{3}\right)$} \\
\hline & $\mathrm{x}$ & SD & $\mathrm{x}$ & SD & $\mathrm{x}$ & SD \\
CII & 107.4 & 55.7 & 509.9 & 125 & 26.1 & 7.3 \\
CIII & 117.8 & 54.8 & 556.5 & 134.9 & 30.2 & 9.6 \\
Difference & 10.4 & & 46.6 & & 4.1 & \\
\hline
\end{tabular}



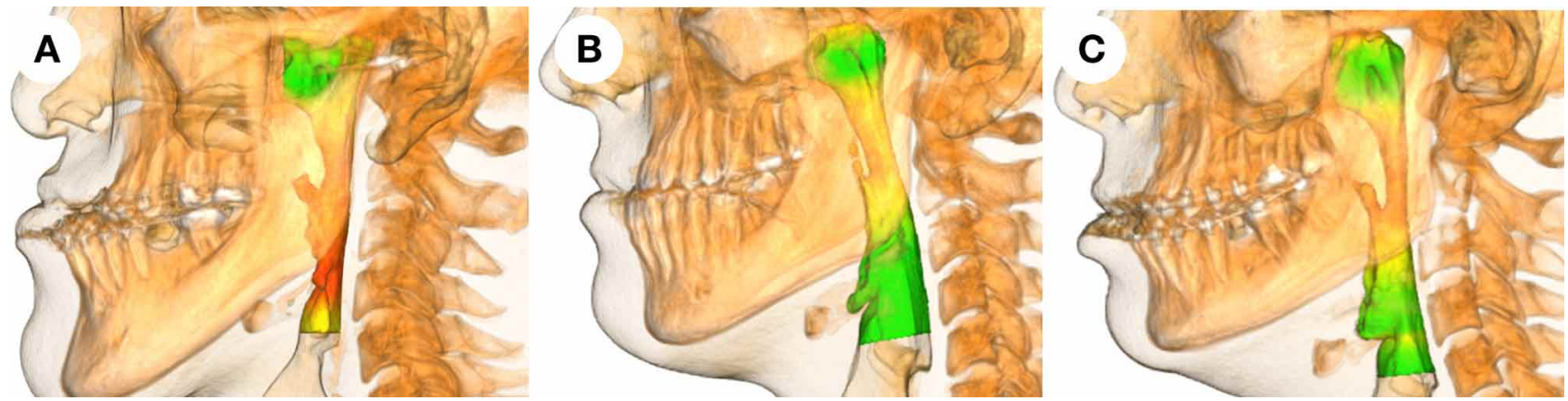

Fig. 1. Subjects with Class III skeletal deformity and observation in airway.
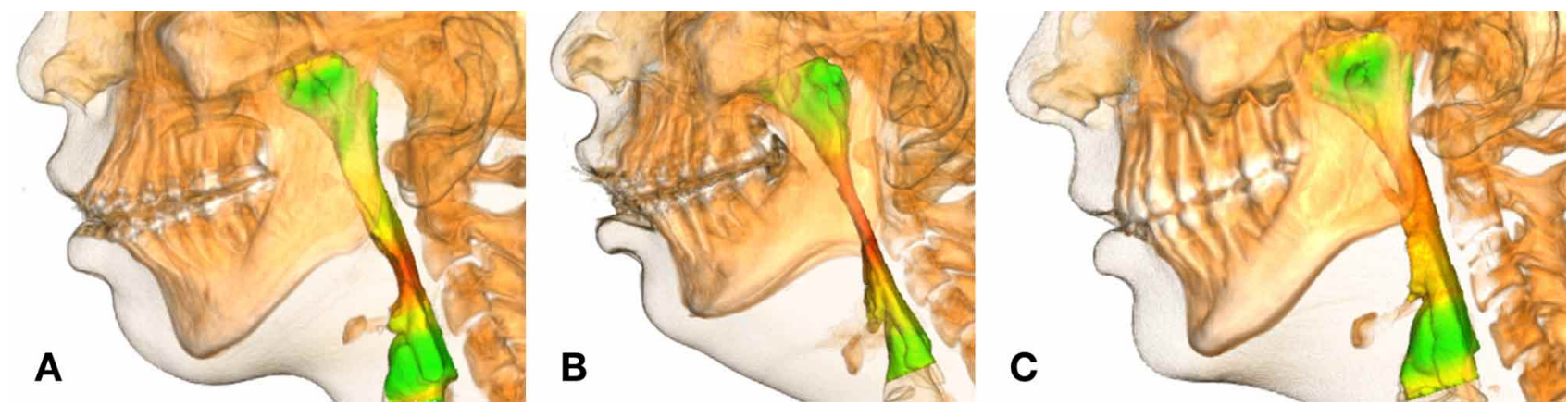

Fig. 2. Subjects with Class II skeletal deformity and observation in airway.

however they still present limitations due to the three-dimensional form of the human body. In 2014, our group (Olate et al., 2014) indicated dimensional changes in the airway by 2D analysis, showing that subjects with Class II facial deformity presented a smaller airway area based exclusively on sagittal measurements. We also indicated that the nasopharynx presented limited differences, showing that the position of the mandible was the most important in this definition since a more retracted position of the hyoid bone was also related with a more retracted position of the mandible.

The morphology of the airway has been reviewed analysing respiratory pathologies like obstructive sleep apnea-hypopnea syndrome (OSAHS). This syndromic disease has a great impact on quality of life and the presence of comorbidities. Jung et al. (2019) indicated that patients with OSAHS present a high risk of cardiovascular morbidity; Kim et al. (2019) also indicated that patients with OSAHS are associated with sub-clinical systemic arteriosclerosis. Thus OSAHS and respiratory pathology are today a potentially destructive problem with important connotations for public health.

In children, a relation has been reported between skeletal alterations like mandibular divergence and the presence of OSAHS, although no cause-effect relation has been identified between craniofacial anomalies and respiratory obstructions (Galeotti et al., 2019). Also in children, a correlation has been reported between reduction in cortical bone tissue and the presence of OSAHS, probably also determining an alteration in bone homeostasis (Eimar et al., 2019).

Our investigation studied the airway conditions of patients with skeletal deformities. OSAHS was not found in any of these patients, however skeletal alterations have been defined as risk factors for the presence of OSAHS. Sakakibara et al. (1999) indicated that in obese patients the increase of soft tissues in the airway zone are an important element in the presence of OSAHS, while in non-obese patients skeletal alterations are more important in the presence of OSAHS. Similar conclusions were presented by Yu et al. (2003), who indicated that narrow nasopharynx and narrow oropharynx are important risk factors for patients with OSAHS.

Although the relation between airway reduction and OSAHS is real, attention has focused on more specific aspects of these relations. Mouhanna-Fattal et al. (2019) compared craniofacial relations in groups with and without OSAHS and they found that the airway volume was smaller in subjects with OSAHS but that this was not necessarily related with craniofacial morphology. Cillo Jr. et al. (2012) found no relation between any of the specific cephalometric variables used and the presence of OSAHS. 
Our results showed that subjects with Class II skeletal deformity presented a smaller airway volume than subjects with Class III deformity; however, some subjects with Class III presented a similar airway volume to Class II subjects. Thus maxillomandibular morphology is not always associated with a reduction in airway volume, and it may be that other variables contribute synergistically to the respiratory pathology.

The airway volume cannot be the only value related with the presence of OSAHS (Susarla et al., 2010). Furthermore, it is difficult to obtain ranges of normality and abnormality for the airway since variables like body mass index, height etc. should be included in determining what volume should be considered normal for the respiratory function and in this scene, surgical treatments like maxillomandibular advancement or body mass reduction (in obese patients) are confirmed as suitable therapies for augmenting the airway and reducing OSAHS (Cillo Jr. \& Dattilo, 2019).

Thus we conclude that airway volume is an important variable in these analyses. It is clear that subjects with Class II deformity have a smaller airway volume than Class III subjects, thus in the presence of OSAHS, one of the treatment objectives must consider modification and augmentation of the airway. Based on our research we may conclude that Class II subjects present a smaller airway volume than Class III subjects.

RAVELO, V.; OLATE, G.; MOYA, M.P.; BRITO, L.; GARAY, I. \& OLATE, S. Análisis 3-D de la via aerea relacionado con la morfología facial. Int. J. Morphol., 38(2):423-426, 2020.

RESUMEN: El objetivo de esta investigación de definir el volumen y área de vía aérea en sujetos con deformidad esqueletal clase II y III. Se diseñó un estudio de corte transversal incluyendo sujetos con deformidad facial definida según análisis de Stainer en sujetos con indicación de cirugía ortognática que presentaran una tomografía computadorizada de haz cónico como elemento diagnóstico; en este examen se determinaron medidas de área mayor, menor de vía aérea y volumen presente; los datos fueron comparados utilizando pruebas estadísticas con el test de spearman considerando el valor de $p<0,05$ para definir significancia estadística. 115 sujetos fueron incluidos, siendo $61,7 \%$ de tipo clase II y $38,3 \%$ de sujetos clase III, con una edad promedio de 27,8 años $( \pm 11,6)$. Se observó una diferencia significativa en mediciones de area y volumen en los grupos estudiados, siendo el grupo de clase II significativamente menor $(\mathrm{p}=0,034)$. $\mathrm{El}$ área de menor tamaño fue 10,4 $\mathrm{mm}^{2}$ en pacientes clase II que en pacientes clase III, mientras que el volumen general de la vía área fue 4,1 menor en los clase II que en los clase III. Es posible concluir que los sujetos de clase II presentan menor volumen de vía área que los sujetos clase III.

PALABRAS CLAVE: Deformidad facial; Vía aérea; SAOS; Cirugía ortognática.

\section{REFERENCES}

Cillo Jr., J. E. \& Dattilo, D. J. Maxillomandibular advancement for severe obstructive sleep apnea is a highly skeletally stable long-term procedure. J. Oral Maxillofac. Surg., 77(6):1231-6, 2019.

Cillo Jr., J. E.; Thayer, S.; Dasheiff, R. M. \& Finn, R. Relations between obstructive sleep apnea syndrome and specific cephalometric measurements, body mass index, and apnea-hypopnea index. J. Oral Maxillofac. Surg., 70(4):e278-83, 2012.

Eimar, H.; Al-Saleh, M. A. Q.; Cortes, A. R. G.; Gozal, D.; Graf, D. \& Flores-Mir, C. sleep-disordered breathing is associated with reduced mandibular cortical width in children. JDR Clin. Trans. Res., 4(1):5867, 2019.

Galeotti, A.; Festa, P.; Viarani, V.; Pavone, M.; Sitzia, E.; Piga, S.; Cutrera, R.; De Vincentiis, G. C. \& D'Antó, V. Correlation between cephalometric variables and obstructive sleep apnoea severity in children. Eur. J. Paediatr. Dent., 20(1):43-7, 2019.

Jung, J. H.; Park, J. W.; Kim, D. H. \& Kim, S. T. The effects of obstructive sleep apnea on risk factors for cardiovascular diseases. Ear Nose Throat J., 2019:145561319882548, 2019.

Kim, S.; Lee, K. Y.; Kim, N. H.; Abbott, R. D.; Kim, C.; Lee, S. K.; Kim, S. H. \& Shin, C. Relationship of obstructive sleep apnoea severity and subclinical systemic atherosclerosis. Eur. Respir. J., 2019. Doi: 10.1183/ 13993003.00959-2019. [Online ahead of print]

Mouhanna-Fattal, C.; Papadopoulos, M.; Bouserhal, J.; Tauk, A.; BassilNassif, N. \& Athanasiou, A. Evaluation of upper airway volume and craniofacial volumetric structures in obstructive sleep apnoea adults: a descriptive CBCT study. Int. Orthod., 17(4):678-86, 2019.

Olate, S.; Cantín, M.; Vásquez, B.; del Sol, M.; Henriquez-Alarcón, M. \& de Moraes, M. Pharyngeal airway space in subjects with class II and class III facial deformities. Int. J. Morphol., 32(4):1271-6, 2014.

Olate, S.; Zaror, C.; Blythe, J. N. \& Mommaerts, M. Y. A systematic review of soft-to-hard tissue ratios in orthognathic surgery. Part III: double jaw surgery procedures. J. Craniomaxillofac. Surg., 44(10):1599-606, 2016.

Sakakibara, H.; Tong, M.; Matsushita, K.; Hirata, M.; Konishi. Y. \& Suetsugu, S. Cephalometric abnormalities in non-obese and obese patients with obstructive sleep apnoea. Eur. Respir. J., 13(2):403-10, 1999.

Susarla, S. M.; Thomas, R. J.; Abramson, Z. R. \& Kaban, L. B. Biomechanics of the upper airway: Changing concepts in the pathogenesis of obstructive sleep apnea. Int. J. Oral Maxillofac. Surg., 39(12):1149-59, 2010.

Yu, X.; Fujimoto, K.; Urushibata, K.; Matsuzawa, Y. \& Kubo, K. Cephalometric analysis in obese and nonobese patients with obstructive sleep apnea syndrome. Chest, 124(1):212-8, 2003.

Corresponding author:

Prof. Sergio Olate

Centro de Excelencia en Estudios Morfológicos

y Quirúrgicos (CEMyQ)

Universidad de La Frontera

Temuco

CHILE

Email: sergio.olate@ufrontera.cl

Received: $10-25-2019$

Accepted: 11-18-2019 